\title{
Integrating a complex rotation with no-till improves weed management in organic farming. A review
}

\author{
Randy L. Anderson
}

Accepted: 23 January 2015 / Published online: 10 March 2015

(C) INRA and Springer-Verlag France 2015

\begin{abstract}
No-till practices are restoring and protecting soil health and are considered critical for achieving sustainability of global agriculture. Organic producers in the USA would like to no-till, but are concerned about managing weeds without tillage. In conventional agriculture, no-till improves weed management in diverse rotations when crops are arranged in 2-year intervals of cool season and warm season crops. A similar approach with organic rotations may enable producers to also accrue the weed management benefit of no-till in organic farming along with restoring soil health. Here, we review the benefits gained for weed management when a complex rotation is integrated with continuous no-till. The complex rotation included 3 years of a perennial legume and 6 years of annual crops arranged in 2-year intervals of warm season or cool season crops. The no-till, complex rotation can (1) reduce weed emergence 3- to 4-fold in some annual crops; (2) delay weed emergence 2 to 4 weeks; (3) reduce yield loss due to weed interference; (4) suppress invasion of dandelion into cropland; and (5) enhance soil restoration, improve nutrient cycling, and increase soil porosity. Furthermore, perennial red clover can be converted to no-till cropland with fall mowing; thus, organic producers can include a perennial legume in a no-till rotation. The complex rotation increases the impact of no-till on weed seed decay in soil and provides numerous opportunities for cover crops to replace tillage for controlling weeds. These benefits suppress weed growth and interference such that organic producers may be able to continuously notill in their farming systems, thus accruing restoration of soil health and long-term sustainability gained with no-till.
\end{abstract}

Keywords Crop diversity · Perennial legume .

Rotation design $\cdot$ Soil health $\cdot$ Systems approach

R. L. Anderson $(\square)$

USDA, 2923 Medary Avenue, Brookings, SD, USA

e-mail: randy.anderson@ars.usda.gov
Contents

1 Introduction

2 Impact of no-till on weed management in a complex rotation

2.1 Controlling weeds during the cool-season crop interval

2.1.1 Underseeding annual clovers in winter wheat

2.1.2 Controlling weeds during the interval from oat to soybean

2.2 Converting a perennial legume to cropland without tillage

2.3 Impact of preceding crop and seeding time on alfalfa competitiveness with weeds

3 Additional benefits of a no-till, complex rotation

3.1 Managing perennial weeds, insect pests, and diseases

3.2 Improved soil functioning and porosity 4 Conclusions

\section{Introduction}

Development of no-till systems, which involves no soil disturbance and direct drilling of crops, has greatly affected agriculture (Triplett and Dick 2008). Producers are restoring soil health, increasing organic matter levels and carbon storage, improving soil structure, and minimizing soil erosion with no-till (Carter 2002; Hobbs 2007). A further benefit is that microbial activity and resource use efficiency increase with no-till (Peigne et al. 2007; Triplett and Dick 2008). Integrating no-till with crop diversity is recognized as critical for achieving sustainability of global agriculture (FAO 2014).

Organic producers are interested in no-till, but they lack viable alternatives to tillage for controlling weeds (Sooby et al. 2007). Scientists are exploring cultural tactics to reduce intensity of tillage (Peigne et al. 2007; Maader and Berner 2012). Methods such as strip tillage (Brainard et al. 2013) or a crimper-roller that mechanically kills cover crops (Kornecki et al. 2009) have been developed. These methods have led to a 
concept of rotational tillage, where reduced or no-till sequences are integrated within a longer tillage-based rotation (Legere et al. 2013). However, results have been inconsistent (Carr et al. 2012). A further concern with rotational tillage is that in conventional agriculture, continuous no-till is more beneficial for improving soil health (Triplett and Dick 2008). Grandy et al. (2006) noted that even a one-time tillage can severely restrict benefits gained from no-till, especially related to soil structure.

Barberi (2002), reviewing weed management in organic farming, questioned if emphasis on specific control tactics was the most effective approach to manage weeds. He speculated that the control tactic approach may neglect the systemic ("holistic") nature of organic agriculture and encouraged researchers to consider system design in addition to control tactics. In conventional agriculture, a systems approach to weed management can reduce the need for herbicides (Deytieux et al. 2012). Integrated weed management involves a multitude of cultural tactics to disrupt weed population dynamics as well as suppress weed interference (Harker 2013; Shaner 2014). One critical component of integrated weed management is rotations composed of a diversity of crops with different life cycles (Colbach et al. 2014; Garrison et al. 2014). Different planting and harvest dates among crops can prevent or reduce weed establishment or seed production. Furthermore, crop diversity can improve crop growth (Kirkegaard and Hunt 2010), thereby increasing crop competitiveness and tolerance to weeds (Anderson 2011).

Producers in the US Great Plains have reduced the cost of weed management $50 \%$ when using a multitactic approach (Anderson 2008). Two trends observed with this program in the Great Plains may be of benefit for organic producers. First, weed dynamics are more disrupted when seasonal crops are arranged in a sequence of two cool season crops followed by two warm season crops. Long-term rotation studies show a 5to 6-fold difference in weed densities when comparing twocrop rotations to four-crop rotations. By preventing weed seed production across 2 years, such as eliminating seed rain of cool season weeds during the warm season crop interval, weed seedling density is drastically reduced when a cool season crop is grown in the third year with no-till.

Second, no-till enhances the impact of rotation design on weed dynamics, but only with rotations composed of two cool season crops followed by two warm season crops (Anderson 2008). Weed density increases in less diverse rotations with no-till, such as two-crop rotations consisting of one cool season crop followed by one warm season crop. The reason notill benefits weed management in four-crop rotations is related to the increased rate of weed seed decay when seeds are maintained on the soil surface (Mohler 2001; Gomez et al. 2014). For example, in the first year after seed rain, density of weed seedlings does not differ between no-till and tilled systems, but by the third year, seedling emergence is 8 -fold greater with tillage (Fig. 1). Seedling emergence with tillage in the third year is higher because weed seeds survive longer buried in soil, leading to more weed seedlings in following years.

Designing rotations to include 2-year intervals of cool and warm season crops has enabled conventional producers, in some no-till rotations, to eliminate herbicide use in three crops out of four because weed density is so low (Anderson 2008). These findings led us to believe that integrating diverse rotations with continuous no-till may enable producers to successfully manage weeds in a no-till organic system. Therefore, we devised a conceptual rotation for the US Great Plains consisting of 3 years of alfalfa (Medicago sativa L.), followed by a 6-year sequence of corn (Zea mays L.)-soybean (Glycine max Merr.)-winter wheat (Triticum aestivum L.)-oat (Avena sativa L.)-soybean-corn, and then alfalfa established with an oat nurse crop (Anderson 2010). The annual crop sequence alternates 2-year intervals of cool season and warm season crops to gain the synergy of no-till and seasonal crop intervals. Alfalfa was included to further enhance the rotation effect on weed dynamics; alfalfa suppresses weeds, especially warm season weeds, due to frequent mowing for forage harvest and competitiveness of the alfalfa canopy (Ominski et al. 1999). We suggested 3 years based on weed seedling emergence across time in alfalfa (Fig. 2). Number of weed seedlings emerging in alfalfa decreases to a minimum 3 or 4 years after establishing alfalfa due to natural decline of viable weed seeds in soil. Seedling emergence increases after 4 years because weeds adapted to alfalfa, such as dandelion (Taraxacum officinale Weber in Wiggers) or downy brome (Bromus tectorum L.), increase in density.

Guided by our conceptual rotation, we review benefits gained by integrating a complex rotation with no-till to manage

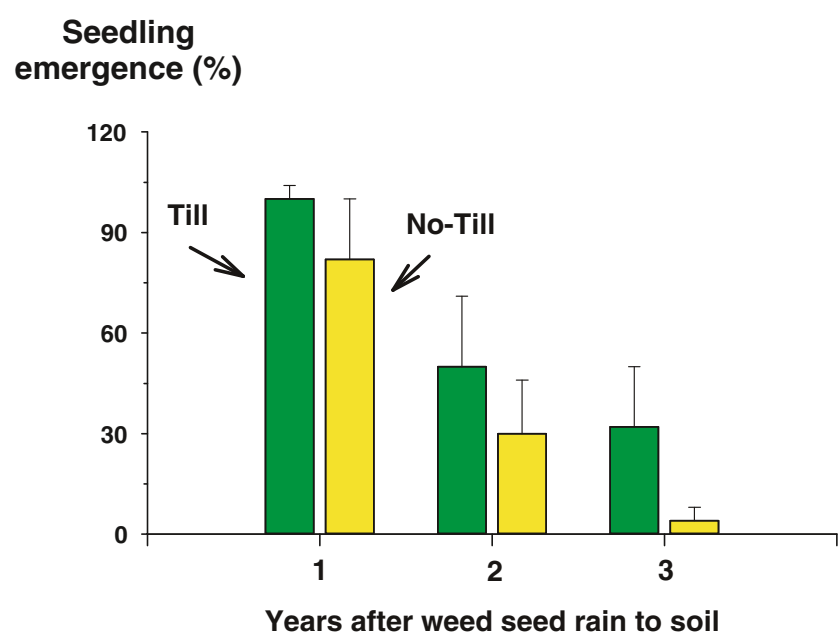

Fig. 1 Weed seedling emergence as affected by tillage and time, averaged across several studies in conventional agriculture. Weed seeds were not added to the soil after initiation of studies; tilled treatment was tilled once a year. Data are expressed as a percentage of the treatment with the highest emergence in the study. Standard error bars were derived from yearly means among studies (adapted from Egley and Williams 1990; Popay et al. 1994; Anderson 2007; Anderson 2009) 


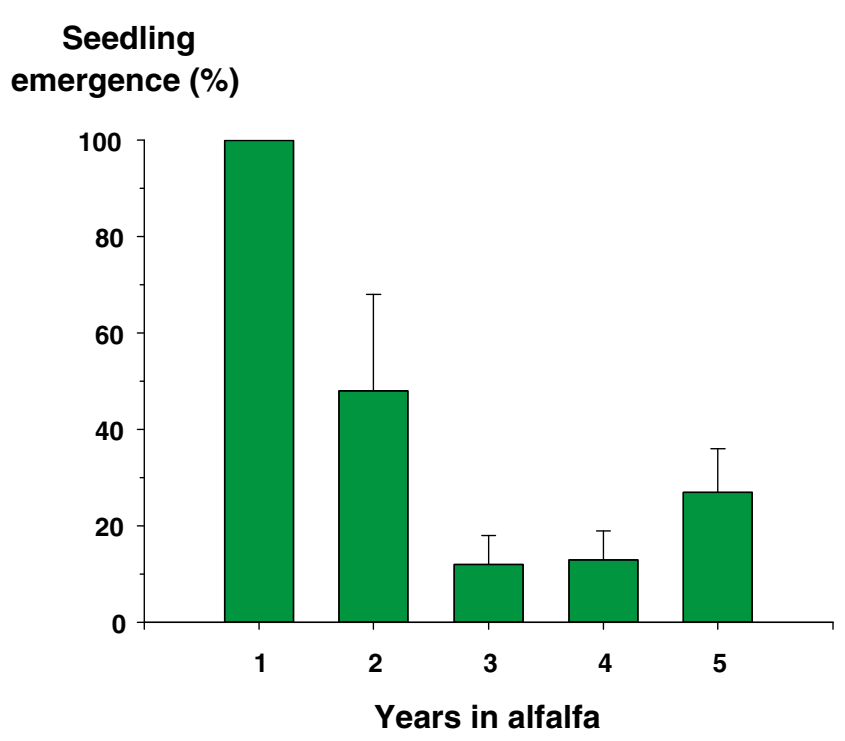

Fig. 2 Seedling emergence of the weed community in alfalfa across time. Data are expressed as a percentage of emergence in the first year and averaged across several studies (adapted from Ominski et al. 1999; Entz et al. 2002; Anderson 2014a)

weeds, based on information from both the literature and recent results from our research program. Currently, a common rotation for organic farming in the Great Plains is a 4-year sequence of alfalfa-corn-soybean-spring wheat with extensive tillage to control weeds and prepare seedbeds. The climate is subhumid, with yearly precipitation ranging from 500 to $650 \mathrm{~mm}$.

\section{Impact of no-till on weed management in a complex rotation}

\subsection{Controlling weeds during the cool season interval}

Cover crops can replace tillage for weed control (Kruidhof et al. 2008; Wilke and Snapp 2008), especially during the cool season interval because of more opportunities to successfully establish cover crops.

\subsubsection{Underseeding annual clovers in winter wheat}

Weed growth after winter wheat harvest can be controlled by underseeding annual clovers into winter wheat (Blaser et al. 2011; Fisher et al. 2011). In our cool season sequence of winter wheat-oat, mammoth red clover (Fig. 3) drilled into winter wheat in the spring reduced weed biomass and volunteer wheat density after winter wheat harvest of $98 \%$ compared with a control (Anderson 2014a). Furthermore, tillage is not needed to terminate annual clovers because they winter-kill.

Underseeded red clover also controlled downy brome by enhancing winterkill. Red clover did not affect seedling emergence of downy brome, but winterkill eliminated all seedlings;

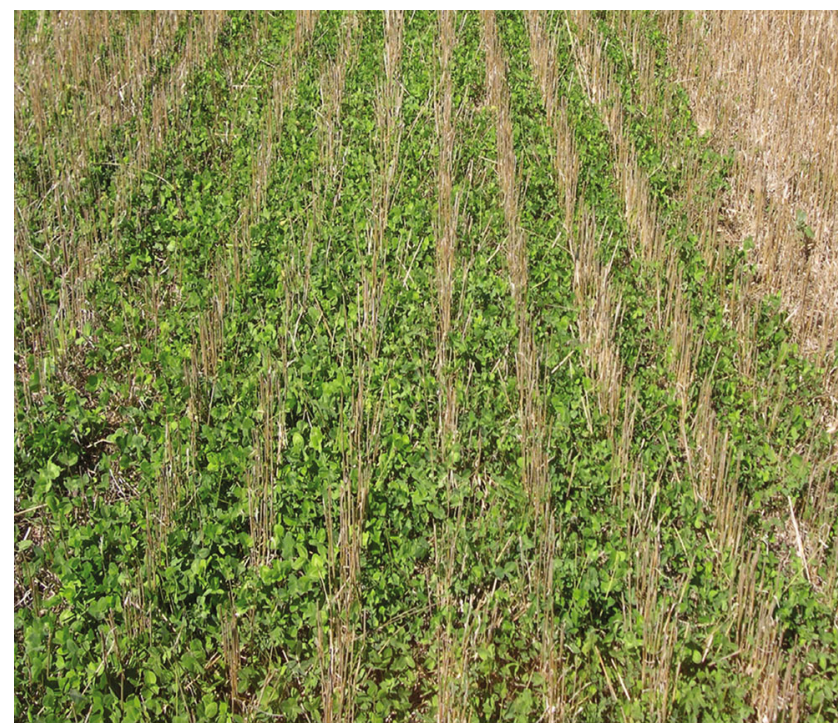

Fig. 3 One benefit of no-till is preserving crop residues on the soil surface to protect soil. Underseeding annual clovers into winter wheat suppresses weeds after harvesting wheat, eliminating the need for tillage to control weeds

in contrast, $60 \%$ of plants emerging in the fall with the control survived the winter. Downy brome produced 9500 seeds $\mathrm{m}^{-2}$ in the control, but only 23 seeds $\mathrm{m}^{-2}$ in the red clover treatment. A mixture of oat/pea planted after oat harvest was also tested in this study, but it reduced downy brome seed production less than $20 \%$ compared with the control (Anderson 2014a).

No-till contributed to brome suppression by red clover. Downy brome seed production in the red clover treatment occurred only with plants emerging in the spring. Yet, several plants of the spring cohort did not vernalize and produce any seeds. Andersson et al. (2002) showed that downy brome emergence was delayed in no-till; in our study, spring emergence of downy brome began in May, 2 to 3 weeks later than it occurs in tilled systems (Werle et al. 2014). Finnerty and Klingman (1962) found that downy brome vernalization was greater with short day lengths. Delay in emergence with no-till led to plants experiencing longer day lengths and warmer temperatures, thus reducing vernalization.

Underseeding red clover eliminated the need for tillage to control weeds after harvesting winter wheat. Winter wheat yield was not reduced by red clover, but some red clover plants survived the winter and infested oat the following year. Therefore, red clover has been replaced with crimson clover (Trifolium incarnatum L.), which is not as winter hardy and completely winterkills (Clark 2012).

\subsubsection{Controlling weeds during the interval from oat to soybean}

Weeds could be controlled in this interval with cover crops that are mechanically terminated (Mischler et al. 2010). For example, Wells et al. (2014) effectively controlled weeds in no- 
till soybean by crimper-rolling winter rye (Secale cereale L.). However, in the Great Plains, this approach often reduces crop yield because of water use by the cover crop, and control of weeds is inconsistent (Carr et al. 2012). Underseeding annual clovers in oat is an option, but possible yield losses of 15 to $20 \%$ in oat may occur (Anderson 2014a). In the eastern US Corn Belt, the cover crop, forage radish (Raphanus sativus L.), effectively controlled winter annual weeds in a corn-soybean rotation (Lawley et al. 2011). Radish winterkilled, thus eliminating the need for tillage, but radish did not control weeds in corn the next year. In contrast, in the Great Plains, a radish-oat mixture planted after oat harvest not only controlled weeds in the fall, but also reduced weed growth $63 \%$ in soybean the following year compared to the tilled control (Anderson 2014b). Soybean yield loss due to weed interference in the no-till, cover crop system was only $17 \%$, but $33 \%$ in the tilled control. Weed interference was less because weed emergence was reduced and delayed in the no-till, cover crop system (Fig. 4). In the tilled control, 50 weed seedlings $\mathrm{m}^{-2}$ emerged in the first 2 weeks after planting soybean, but with no-till, 6 weeks passed before 50 seedlings had emerged. Total weed emergence after 8 weeks was 4-fold higher in the tilled control.

Our results differ from Lawley et al. (2011) for two reasons. First, our study involved a winter wheat-oat-soybean sequence rather than a corn-soybean rotation. In conventional agriculture, tilling after a 2-year interval of no-till in winter wheat-oat sequence increased weed emergence in soybean 5fold compared to continuous no-till (Anderson 2009), a similar trend as shown in Fig. 4. The 2 years of cool season cereal

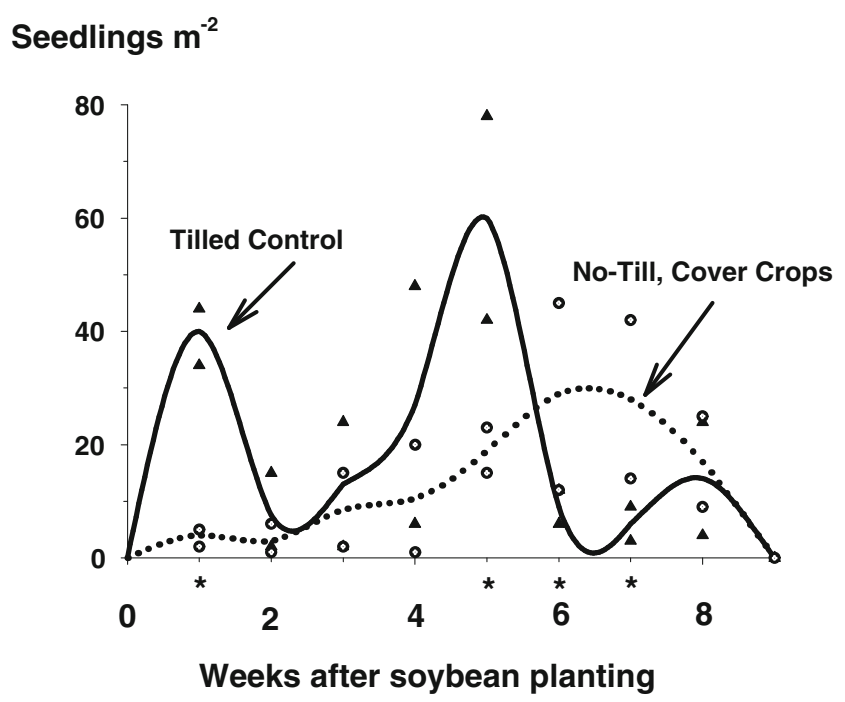

Fig. 4 Weed emergence pattern in soybean, comparing a no-till, cover crop system (circle symbols) with a tilled control (triangle symbols). Crop sequence before treatments were established was winter wheat-oat in notill. Data were collected weekly for the first 8 weeks after soybean planting; data averaged across two studies. Asterisks beneath the X-axis indicate that emergence in that week differed between systems at the 0.05 level of probability. Study conducted at Brookings SD, USA (adapted from Anderson 2014b) crops followed by no-till soybean favored the decline of viable weed seeds in the soil, thus reducing weed density (as shown in Fig. 1). A second difference is our continued no-till into the soybean growing season preserved crop residues lying on the soil surface. Crop residues delay the time of weed emergence (Teasdale et al. 2007; Bernstein et al. 2014).

Cover crops eliminated the need for tillage to control weeds in the no-till winter wheat-oat-soybean sequence of our 9-year rotation. Weed interference in no-till soybean can be further reduced by between-row mowing (Donald et al. 2001) and inrow control of weeds (Wortman 2014).

\subsection{Converting a perennial legume to cropland without tillage}

Perennial legumes can be converted to annual cropland without tillage by mowing twice in the fall (between September 1 and October 31) in the third year of forage (Anderson 2014a). This tactic effectively suppressed medium red clover (Trifolium pratense $\mathrm{L}$.) such that corn could establish in the following year. Death of red clover occurred over winter because mowing reduced carbohydrate levels in the crown and roots; perennial legumes use $50 \%$ of their stored carbohydrates to survive the winter (Sheaffer et al. 1988). Producers in the Great Plains are encouraged to not harvest legumes in the fall to avoid stand loss due to winterkill (Haagenson et al. 2004).

Biomass of fall-mowed red clover was more than $80 \%$ less than mowed alfalfa 3 and 6 weeks after planting corn (Fig. 5). Furthermore, stand density of mowed red clover was $85 \%$ lower than alfalfa (Anderson 2014a). Corn established only in mowed red clover, but not in any of the alfalfa treatments nor

\section{Biomass \\ $\left(\mathrm{g} \mathrm{m}^{-2}\right)$}

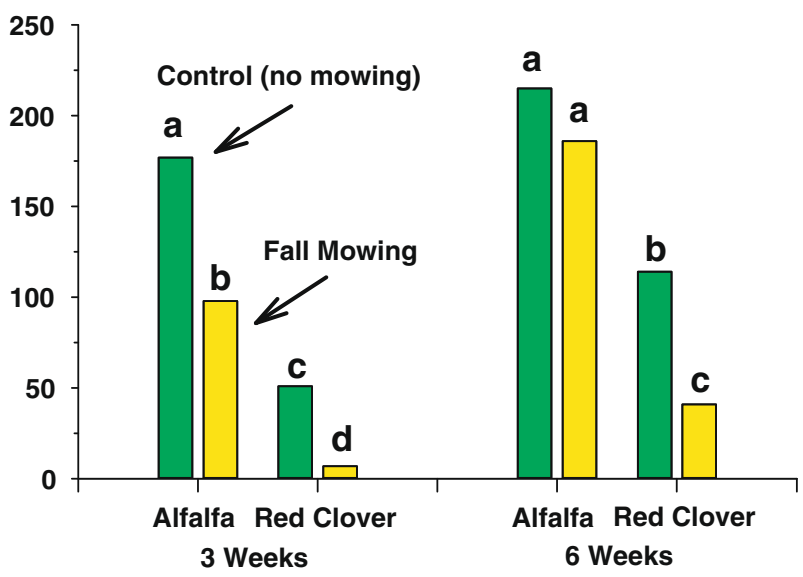

Sampling

(weeks after corn planting)

Fig. 5 Biomass of alfalfa or red clover in corn planted the fourth year after mowing the legumes in the fall of the third year. Data were averaged across two studies. Bars with identical letters are not significantly different as determined by Fisher's LSD (0.05). Study conducted at Brookings SD, USA. $R C$ red clover (Anderson 2014a) 
the red clover control where early season competition killed corn seedlings. Corn grain yield was reduced $45 \%$ by volunteer red clover and weeds in the mowed red clover treatments, but weeds reduced corn similarly in a tillage-based control (tillage in the fall and before corn planting). Producers in a tilled system can control weeds in the crop with tillage to minimize yield loss, but producers in no-till also can control weeds and volunteer clover because of innovations with equipment. Donald et al. (2001) designed a mower that effectively controls weeds between rows of corn and soybean, eliminating the need for tillage or herbicides between rows. Other implements can remove weeds in the crop row (Van der Weide et al. 2008; Wortman 2014). With these implements, weeds and volunteer red clover in corn can be controlled without tillage. Late season growth of red clover would be suppressed by shading of corn.

Weed biomass measured 9 weeks after planting corn in the fall-mowed red clover treatment was less than $10 \%$ of weed biomass in the tilled treatment (Anderson 2014a). Volunteer red clover was also present, but biomass of both was only $50 \%$ of weed biomass in the tilled treatment. Part of this contrast in weed biomass was related to no-till. Weekly assessments of weed emergence in the weed-free subplots of corn showed that weed emergence in the tilled treatment was 3 times higher than that in fall-mowed red clover (Fig. 6). Tilling increased weed emergence in corn. Similar trends have been observed in conventional agriculture; weed density in annual crops is higher when alfalfa is terminated by tillage compared with no-till (Ominski and Entz 2001).

\section{Weed emergence (plants $\mathrm{m}^{-2}$ )}

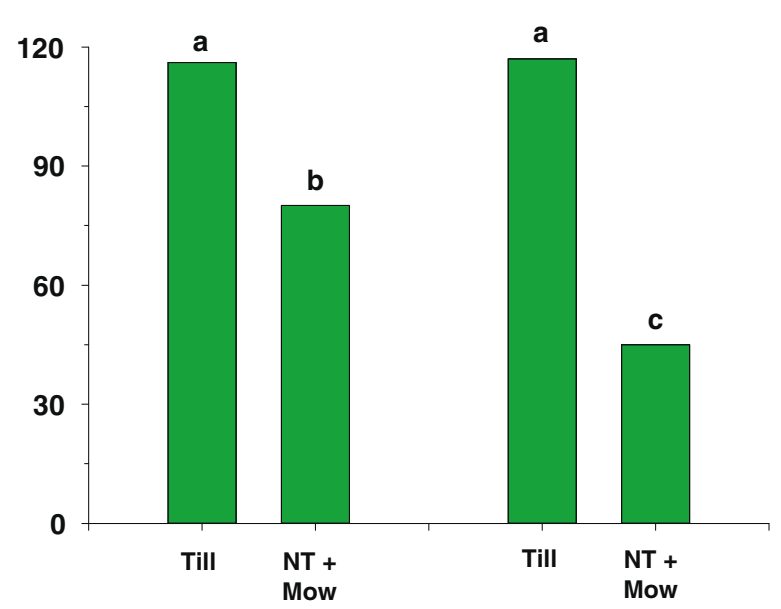

\section{Alfalfa}

\section{Red Clover}

Fig. 6 Weed seedling emergence during the 9 weeks following corn planting. Data collected in subplots where legumes were eliminated by herbicides. Data were averaged across two studies. Bars with identical letters are not significantly different as determined by Fisher's LSD (0.05). Study conducted at Brookings SD, USA. NT no-till (Anderson 2014a)
2.3 Impact of preceding crop and seeding time on alfalfa competitiveness with weeds

A common practice for organic farming is establishing alfalfa after spring wheat harvest, with the field tilled to prepare a seedbed. However, organic no-till alfalfa is most competitive with weeds following soybean (Anderson 2014a). In the third forage year (preceding fall mowing for conversion to cropland), weed biomass in alfalfa following spring wheat was $23 \%$ of the plant community, but less than $1 \%$ when alfalfa followed soybean (Fig. 7). Alfalfa yield was also $19 \%$ higher following soybean.

Weed biomass increased because alfalfa density following spring wheat was only $71 \%$ of alfalfa following soybean (Anderson 2014a). Weeds such as downy brome and dandelion were able to establish and produce biomass where alfalfa stand was sparse. In the third forage year, downy brome infested $21 \%$ of the land area in alfalfa following spring wheat, but was not observed in alfalfa following soybean.

Alfalfa establishment following spring wheat harvest was reduced because some seedlings died due to competition from spring wheat volunteers and growth of annual weeds that established in spring wheat. Few volunteers of soybean and corn established in alfalfa, and seedlings of warm season weeds that infested soybean and corn the previous year did not emerge until after alfalfa seedlings were established. Alfalfa establishment following corn was disrupted somewhat by corn residues on the soil surface interfering with proper seed placement during alfalfa planting.

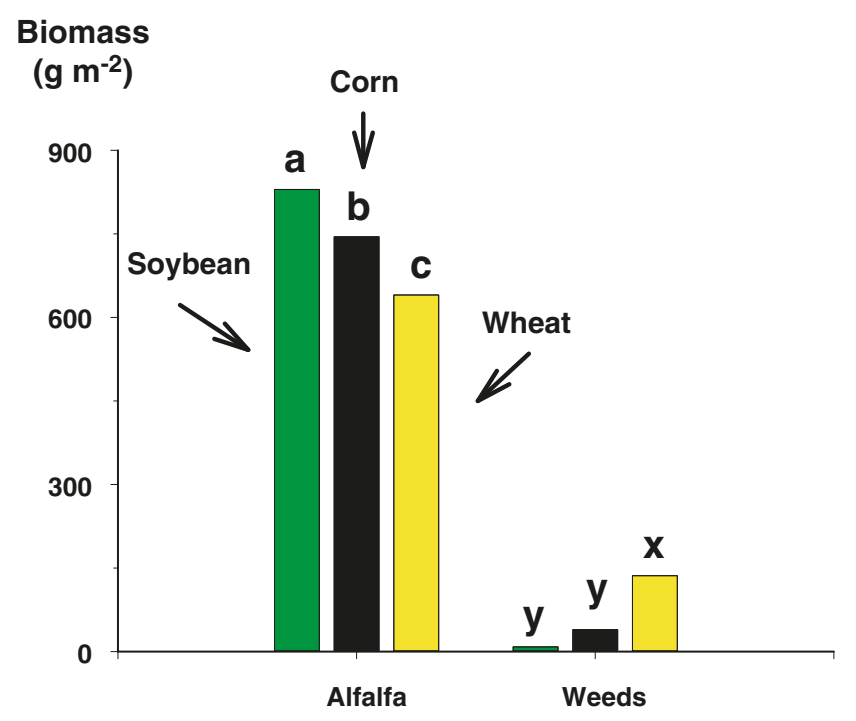

Fig. 7 Biomass (fresh weight) of alfalfa and weeds as affected by the preceding crop, soybean, corn, or spring wheat. Data were collected in the third year of alfalfa and averaged across three sampling dates (late May, early July, and late August) and two studies. Bars with the same letter within either alfalfa or weed biomass are not significantly different as determined by Fisher's LSD (0.05). Study conducted at Brookings SD, USA (Anderson 2014a) 


\section{Additional benefits of a no-till, complex rotation}

\subsection{Managing perennial weeds, insect pests, and diseases}

Perennial weeds can be a major obstacle to successful organic farming, especially in systems with less tillage (Albrecht 2005; Sooby et al. 2007). Yet, crop selection and sequence within a rotation can help manage perennial weeds. In our red clover conversion study described above, dandelion density in the third year of forage was 4-fold higher in alfalfa than that in red clover (Anderson 2014a). Also, density of prickly lettuce (Latuca serriola L.), an annual species whose seed is wind-distributed like dandelion, was 10-fold higher in alfalfa than that in red clover. Red clover is more competitive with these weeds than alfalfa. Dandelion density in alfalfa also was influenced by the crop which preceded alfalfa. Assessed in the third year of forage, dandelion density was 10-fold higher in alfalfa following spring wheat than following soybean, and 3fold higher when alfalfa followed corn compared with soybean.

Canada thistle [Cirsium arvense (L.) Scop.] is also present in the Great Plains. Perennial legumes effectively control Canada thistle because repeated mowing and competition disrupts carbohydrate storage in the crown and roots (Moore 1975). Donald (1990) reported that Canada thistle can be eliminated with 3 years of perennial legumes. Sudangrass [Sorghum sudanense (Piper) Stapf.] suppresses fall growth of Canada thistle because of its rapid growth and canopy development (Bicksler et al. 2012). A warm season plant, sudangrass, can be planted as a cover crop after winter wheat or oat harvest. Also, in-crop mowing in corn and soybean will reduce Canada thistle growth (Donald et al. 2001).

Our complex rotation will also help manage two prevalent pests in the US Corn Belt. Soybean cyst nematode (Heterodera glycines Ichinohe) is the most prominent disease infecting soybean in the USA (Wrather and Koenning 2006). Miller et al. (2006) found that red clover and alfalfa serve as quasi-hosts for this nematode, stimulating eggs to break dormancy. But, nematodes are unable to complete their life cycle and reproduce on these species; thus, these legumes accelerate decline of nematode density in soil. A major pest in corn is the corn rootworm (Diabrotica spp.), and diversifying the crop rotation effectively suppresses this pest also (Levine et al. 2002).

\subsection{Improving soil functioning and porosity}

This 9-year rotation can restore soil health and consequently, increase crop yields. Karlen et al. (2006) found that soil health improved when rotations included 3 years of perennial forages, but soil health declined with continuous corn or cornsoybean. Stanger and Lauer (2008) reported corn yields $17 \%$ more in a rotation with 3 years of alfalfa than either continuous corn or corn-soybean, which was attributed to improved soil functioning.

This complex rotation will also aid nutrient management. Annual crops have responded to biological $\mathrm{N}$ from perennial legumes for 3 to 5 years after termination (Hoyt 1990; Sweeney and Moyer 2004). Perennial legumes reduce nitrate leaching in soil because of their deep rooting structure, thus recycling more $\mathrm{N}$ for crop growth (Dinnes et al. 2002; Entz et al. 2002). Legumes also increase organic P levels in soil by releasing acids to solubilize fixed P (Gallaher and Snapp 2014). Long-term studies show that organic rotations with perennial legumes maintain similar bioavailable $\mathrm{P}$ levels as found with conventional rotations using $\mathrm{P}$ fertilizers (Wortman et al. 2012; Gallaher and Snapp 2014). Grandy et al. (2006) and Brussaard et al. (2007) both noted that nutrient use efficiency is higher in no-till, diverse cropping systems because of microbial changes in soil.

Red clover can alleviate soil compaction near the surface. Papadopoulos et al. (2006) found that red clover increased soil macroporosity and average pore size compared with spring wheat or hairy vetch (Vicia villosa Roth). Also, Grandy et al. (2006) noted that over time, soil compaction in no-till is ameliorated due to gradual buildup of organic matter and microbial activity near the soil surface.

\section{Conclusions}

Integrating no-till with a rotation that includes seasonal intervals of two cool season and two warm season crops along with a perennial legume improves weed management. Weed density is reduced, and time of emergence is delayed, thus lessening impact of weeds on crop growth. Furthermore, soil functioning and porosity improves with no-till, diverse rotations. Red clover can be converted to cropland with fall mowing, thus eliminating the need for tillage when organic rotations include a perennial legume.

Diverse crop rotations can reduce weed density in tillagebased organic systems (Cavigelli et al. 2008; Koocheki et al. 2009); integrating no-till with diverse rotations should further decrease weed density. Lower weed density and delayed emergence also will lead to higher efficacy of cultural tactics (Zasada et al. 1997; Dieleman et al. 1999; Rasmussen 2004).

Future research should field test this conceptual rotation, especially if recently developed equipment, such as the between-row mower, can be integrated with weed management. Also, methods to establish cover crops in corn or soybean to suppress late season weed growth are needed; aerial applications of cover crop seed may be one possibility (Wilson et al. 2014). The conceptual rotation has been revised by replacing alfalfa with red clover and changing the sequence of crops in the second warm season interval to corn-soybean. 
Barberi (2002) suggested that examples of system designs for weed management in organic farming be described in the literature to stimulate more consideration of the systems approach. Zwickle et al. (2014) also encouraged scientists to provide examples that demonstrate how long-term, diverse rotations are crucial for integrated weed management in organic rotations. Our proposed rotation is one example and may provide ideas for producers and scientists elsewhere to develop similar programs. Integrating no-till with a complex rotation may improve weed management such that producers could develop a continuous no-till organic system.

\section{References}

Albrecht H (2005) Development of arable weed seedbanks during the 6 years after the change from conventional to organic farming. Weed Res 45:339-350. doi:10.1111/j.1365-3180.2005.00472.x

Anderson RL (2007) Crop sequence and no-till reduce seedling emergence of common sunflower (Helianthus annuus) in following years. Weed Technol 21:355-358. doi:10.1614/WT-06-109.1

Anderson RL (2008) Diversity and no-till: keys for pest management in the U.S. Great Plains. Weed Sci. doi:10.1614/WT-07-007.1

Anderson RL (2009) A 2-year small grain interval reduces need for herbicides in no-till soybean. Weed Technol 23:398-403. doi:10.1614/ WT-09-030.1

Anderson RL (2010) A rotation design to reduce weed density in organic farming. Renew Agric Food Syst 25:189-195. doi:10.1017/ S1742170510000256

Anderson RL (2011) Synergism: a rotation effect of improved growth efficiency. Adv Agron 112:205-226. doi:10.1016/B978-0-12385538-1.00005-6

Anderson RL (2014a) Unpublished research

Anderson RL (2014b) A cultural system to reduce weed interference in organic soybean. Renew Agric Food Syst. doi:10.1017/ S1742170514000167

Andersson L, Milberg P, Schutz W, Stenimetz O (2002) Germination characteristics and emergence time of annual Bromus species of differing weediness in Sweden. Weed Res 42:135-147

Barberi P (2002) Weed management in organic agriculture: are we addressing the right issues? Weed Res 42:177-193

Bernstein ER, Stoltenberg DE, Posner JL, Hedtcke JL (2014) Weed community dynamics and suppression in tilled and no-tillage transitional organic winter rye-soybean systems. Weed Sci 62:125-137. doi:10. 1614/WS-D-13-00090.1

Bicksler AJ, Masiunas JB, Davis A (2012) Canada thistle (Cirsium arvense) suppression by Sudangrass interference and defoliation. Weed Sci 60:260-266. doi:10.1614/WS-D-11-00145.1

Blaser BC, Singer JW, Gibson LR (2011) Winter cereal canopy effect on cereal and interseeeded legume productivity. Agron J 103:1180 1185. doi:10.2134/agronj2010.0506

Brainard DC, Peachey E, Haramoto E, Luna J, Rangarajan A (2013) Weed ecology and management under strip tillage: implications for Northern U.S. vegetable cropping systems. Weed Technol 27: 218-230. doi:10.1614/WT-D-12-00068.1

Brussaard L, de Ruiter PC, Brown GC (2007) Soil biodiversity for agricultural sustainability. Agric Ecosyst Environ 121:233-244. doi:10. 1016/j.agee.2006.12.013

Carr PM, Anderson RL, Lawley YE, Miller PR, Zwinger SF (2012) Organic zero-till in the northern Great Plains region: opportunities and obstacles. Renew Agric Food Syst 27:2-6. doi:10.1017/ S174217051100041X

Carter MR (2002) Soil quality for sustainable land management: organic matter and aggregation interactions that maintain soil functions. Agron J 94:38-47

Cavigelli MA, Teasdale JR, Conklin AE (2008) Long-term agronomic response of organic and conventional field crops in the Mid-Atlantic region. Agron J 100:785-794. doi:10.2134/agronj2006.0373

Clark A (2012) Managing Cover Crops Profitably, 3rd edn. Sustainable Agriculture Research and Education handbook series 9. Pp 159-164

Colbach N, Biju-Duval L, Gardarin A, Granger S, Guyot SHM, Meziere D, Munier-Jolain NM, Petit S (2014) The role of models for multicriteria evaluation and multiobjective design of cropping systems for managing weeds. Weed Res 54:541-555. doi:10.1111/wre. 12112

Deytieux V, Nemceck T, Knuchel RF, Gaillard G (2012) Is integrated weed management efficient for reducing environmental impacts of cropping systems? A case study based on life cycle assessment. Europ J Agron 36:55-65. doi:10.1016/j.eja.2011.08.004

Dieleman JA, Mortensen DA, Martin AR (1999) Influence of velvetleaf (Abutilon theophrasti) and common sunflower (Helianthus annuus) density variation on weed management outcomes. Weed Sci 47:8187

Dinnes DL, Karlen DL, Jaynes DB, Kaspar TC, Hatfield JL, Colvin TS, Cambardella CA (2002) Nitrogen management strategies to reduce nitrate leaching in tile-drained Midwestern soils. Agron J 94:153171

Donald WW (1990) Management and control of Canada thistle (Cirsium arvense). Rev Weed Sci 5:193-250

Donald WW, Kitchen NR, Sudduth KA (2001) Between-row mowing plus banded herbicide to control annual weeds and reduce herbicide use in no-till soybean (Glycine max) and corn (Zea mays). Weed Technol 15:576-584

Egley GH, Williams RD (1990) Decline of weed seeds and seedling emergence over five years as affected by soil disturbance. Weed Sci 38:504-510

Entz MH, Baron VS, Carr PM, Meyer DW, Smith SR Jr, McCaughey WP (2002) Potential of forages to diversify cropping systems in the Northern Great Plains. Agron J 94:240-250

FAO (2014) What is Conservation Agriculture? Food and Agriculture Organization CA website http://www.fao.org/ag/ca/1a.thml. Accessed December 4, 2014

Finnerty DW, Klingman DL (1962) Life cycles and control studies of some weed bromegrasses. Weeds 10:40-47

Fisher KA, Momen B, Kratochvil RJ (2011) Is broadcasting seed an effective winter cover crop planting method? Agron J 103:472-478

Gallaher C, Snapp SS (2014) Organic management and legume presence maintained phosphorus bioavailability in a 17-year field crop experiment. Renew Agric Food Syst. doi:10.1017/S1742170513000380

Garrison AJ, Miller AD, Ryan MR, Roxburgh SH, Shea K (2014) Stacked crop rotations exploit weed-weed competition for sustainable weed management. Weed Sci 62:166-176. doi:10.1614/WS-D13-00037.1

Gomez R, Liebman M, Munkvold G (2014) Weed seed decay in conventional and diversified cropping systems. Weed Res 54:13-25. doi: 10.1111/wre. 12052

Grandy AS, Robertson GP, Thelen KD (2006) Do productivity and environmental trade-offs justify periodically cultivating no-till cropping systems? Agron J 98:1377-1383

Haagenson DM, Cunningham SM, Joern BC, Volenec JJ (2004) Autumn defoliation effects on alfalfa winter survival, root physiology, and gene expression. Crop Sci 43:13340-1348

Harker KN (2013) Slowing weed evolution with integrated weed management. Can J Plant Sci 93:759-764 
Hobbs PR (2007) Conservation agriculture: what is it and why is it important for future sustainable food production. J Agric Sci 145:127137. doi:10.1017/S0021859607006892

Hoyt PB (1990) Residue effects of alfalfa and bromegrass cropping on yields of wheat grown for 15 subsequent years. Can J Plant Sci 70: 109-113

Karlen DL, Hurley EG, Andrews SS, Cambardella CA, Meek DW, Duffy MD, Mallarino (2006) Crop rotation effects on soil quality at three northern corny/soybean belt locations. Agron J 98:484-495

Kirkegaard JA, Hunt JR (2010) Increasing productivity by matching farming system management and genotype in water-limited environments. J Exp Biol 61:4129-4143. doi:10.1093/jxb/erq245

Koocheki A, Nassiri M, Alimoradi L, Ghorbani R (2009) Effect of cropping systems and crop rotations on weeds. Agron Sust Dev 29:401-408. doi:10.1051/agro/2008.061

Kornecki TS, Price AJ, Raper RL, Arriaga FJ (2009) New roller crimper concepts for mechanical termination of cover crops in conservation agriculture. Renew Agric Food Syst 24:165-173. doi:10.1017/ S1742170509002580

Kruidhof HM, Bastiaan L, Kropff MJ (2008) Ecological weed management by cover cropping: effects of weed growth in autumn and weed establishment in spring. Weed Res 48:492-502. doi:10.1111/j.13653180.2008.00665.x

Lawley YE, Weil RR, Teasdale JR (2011) Forage radish cover crop suppresses winter annual weeds in fall and before corn planting. Agron J 103:137-144. doi:10.2134/agronj2010.0187

Legere A, Shirtliffe SJ, Vanasse A, Gulden RH (2013) Extreme grainbased cropping systems: when herbicide-free weed management meets conservation tillage in Northern climates. Weed Technol 27: 204-211. doi:10.1614/WT-D-12-00074.1

Levine E, Spencer JL, Isard SA, Onstad DW, Gray ME (2002) Adaptation of the western corn rootworm to crop rotation: evolution of a new strain in response to a management practice. Am Entomol 48:94 107

Maader P, Berner A (2012) Development of reduced tillage systems in organic farming in Europe. Renew Agric Food Syst 27:7-11

Miller DR, Chen SY, Porter PM, Johnson GA, Wyse DL, Stetina SR, Klossner LD, Nelson GA (2006) Rotation crop evaluation for management of the soybean cyst nematode in Minnesota. Agron J 98: 569-578. doi:10.2134/agronj2005.0185

Mischler R, Duiker SW, Curran WS, Wilson D (2010) Hairy vetch management for no-till organic corn production. Agron J 102:355-362

Mohler CL (2001) Mechanical management of weeds. In: Liebman M, Mohler CL, Staver CP (eds) Ecological Management of Agricultural Weeds. Cambridge University Press, United Kingdom, pp 139-209

Moore RJ (1975) The biology of Canadian weeds. 13. Cirsium arvense (L.)Scop. Can J Plant Sci 55:1033-1048

Ominski PD, Entz MH (2001) Eliminating soil disturbance reduces postalfalfa summer annual weed populations. Can J Plant Sci 81:881884

Ominski PD, Entz MH, Kenkel N (1999) Weed suppression by Medicago sativa in subsequent cereal crops: a comparative survey. Weed Sci 47:282-290

Papadopoulos A, Mooney SJ, Bird NRA (2006) Quantification of the effects of contrasting crops in the development of soil structure: an organic conversion. Soil Use Manage 22:172-179. doi:10.1111/j. 1475-2743.2005.00004.x

Peigne J, Ball BC, Roger-Estrade J, David C (2007) Is conservation tillage suitable for organic farming? A review. Soil Use Manage 23:129-144. doi:10.1111/j.1475-2743.2006.00082.x
Popay AL, Cox TI, Ingle A, Kerr R (1994) Effects of soil disturbance on weed seedling emergence and its long-term decline. Weed Res 34: 403-412

Rasmussen KJ (2004) The effect of growing date, stale seedbed, row width, and mechanical weed control on weeds and yields of organic winter wheat. Weed Res 44:12-20

Shaner DL (2014) Lessons learned from the history of herbicide resistance. Weed Sci 62:427-431. doi:10.1614/WS-D-13-00109.1

Sheaffer CC, Lacefield GD, Marble VL (1988) Cutting schedules and stand. In: Hanson AA, Barnes DK (eds) Agronomy. Wisconsin, Madison, pp 411-437

Sooby J, Landeck J, Lipson (2007) National Organic Research Agenda. Organic Farming Research Foundation, Santa Cruz, CA. Web page: orfr.org. Accessed: July 22, 2014

Stanger TF, Lauer JG (2008) Corn grain yield response to crop rotation and nitrogen over 35 years. Agron J 100:643-650. doi:10.2134/ agronj2007.0280

Sweeney DW, Moyer JL (2004) In-season nitrogen uptake by grain sorghum following legume green manures in conservation tillage systems. Agron J 96:510-515

Teasdale JR, Brandsaeter LO, Calegari A, Skora Neto F (2007) Cover crops and weed management. In: Upadhyaya MK, Blackshaw RE (eds) Non-Chemical Weed Management. CAB International, Cambridge MA, pp 49-64

Triplett GB Jr, Dick WA (2008) No-tillage crop production: a revolution in agriculture. Agron J 100(Suppl):S-153-S-115. doi:10.2134/ agronj2007.0005c

Van der Weide RY, Bleeker PO, Achten WT, Lotz LA, Fogelbery F, Melander B (2008) Innovation in mechanical weed control in crop rows. Weed Res 48:215-224. doi:10.1111/j.1365-3180.2008.00629.

Wells MS, Reberg-Horton SC, Mirsky SB (2014) Cultural strategies for managing weeds and soil moisture in cover crop based no-till soybean production. Weed Sci 62:501-511. doi:10.1614/WS-D-1300142.1

Werle R, Bernards ML, Arkebauer TJ, Lindquist JL (2014) Environmental triggers of winter annual weed emergence in the Midwestern United States. Weed Sci 62:83-96. doi:10.1614/WSD-13-00091.1

Wilke BJ, Snapp SS (2008) Winter cover crops for local ecosystems: linking plant traits and ecosystem function. J Sci Food Agric 88: 551-557. doi:10.1002/jsfa.3149

Wilson ML, Allan DL, Baker JM (2014) Aerially seeding cover crops in the northern US Corn Belt: limitations, furtuer research needs, and alternative practices. J Soil Water Conserv 69:67A-72A. doi:10. 2489/jsws.69.3.67A

Wortman SE (2014) Integrating weed and vegetable crop management with multifunctional air-propelled abrasive grits. Weed Technol 28: 243-252. doi:10.1614/WT-D-13-00105.1

Wortman SE, Galusha TD, Mason SC, Francis CA (2012) Soil fertility and crop yields in long-term organic and conventional cropping systems in eastern Nebraska. Renew Agric Food Syst 27:200-216. doi: $10.1017 /$ S1742170511000317

Wrather JA, Koenning SR (2006) Estimates of disease effects on soybean yields in the United States 2003-2005. J Nemat 38:173-180

Zasada IA, Linker HM, Coble HD (1997) Initial weed densities affect notill weed management with a rye (Secale cereale) cover crop. Weed Technol 11:473-477

Zwickle S, Wilson R, Doohan D (2014) Identifying the challenges of promoting ecological weed management (EWM) in organic ecosystems through the lens of behavioral decision making. Agric Hum Values 31:355-370. doi:10.1007/s10460-014-9485-7 